\title{
The Influence of Self Regulated Learning to Mathematics Critical Thinking Ability on 3D-Shapes Geometry Learning using Geogebra
}

\author{
Destia Wahyu Hidayati ${ }^{1 *}$, Lenny Kurniati ${ }^{2}$ \\ 1,2Program Studi Pendidikan Matematika, IKIP Veteran Jawa Tengah Jalan Pawiyatan Luhur IV/17 \\ Semarang, Indonesia \\ *Email: destia281289@gmail.com
}

Article received: 06-08-2018, article revised:03-09-2018, article published: 07-09-2018

DOI : 10.25273/jipm.v7i1.2965

\begin{abstract}
3D-Shapes Geometry is one of the subjects material that must be taught to students in Mathematics Education Program, which later after graduation will become a math teacher. Learning 3D-Shapes Geometry has relevance to the mathematics critical thinking ability. Students who have the ability to think critically can think rationally by collecting information as completely as possible. Learning that can stimulate the ability of critical thinking should be learning in which there are activities that are student-centered learning. One of the lessons in 3D-Shapes Geometry that can be used is learning using Geogebra Software. Learning 3DShapes Geometry using GeoGebra aided is very possible to make students practice independently spatial capabilities that will foster self-regulated learning. The existence of self-regulated learning in the student's learning will make the students able to interpret, analyze, evaluate, and infer in learning. These capabilities will form the mathematics critical thinking ability. The purpose of this research is to determine whether or not there is a relationship between self-regulated learning and mathematics critical thinking ability and to find out coefficient of correlation of them. This research is a quantitative research. Before the research begins, the researchers took the value of the task as the preliminary data and it is tested normality. Data collection techniques in this research is the scale of self-regulated learning and tests in the form of mathematics critical thinking ability. The scale of selfregulated learning and mathematics critical thinking ability tests are validated first. Data test of mathematics critical thinking ability of is tested normality, then data of scale self-regulated learning and test of mathematics critical thinking ability are tested regression. The result of this research is there is influence of self-regulated learning to the mathematics critical thinking ability of $45,7 \%$.
\end{abstract}

Keywords : Self-Regulated Learning; Mathematics Critical Thinking Ability; Geogebra 



\section{INTRODUCTION}

Education is one of the efforts that is taken in order to educate the lives of the nation (Wahyuni, 2017). Education has a close relation with subject matter. Mathematics is one of compulsory subject matter in school (Hidayati, 2017a). Mathematics will be met in every level of school (Hidayati, 2017b). 3D-Shapes Geometry is one of the subjects that must be taught to students in the Mathematics Education Study Program. According to Kemendikbud (2016), students are expected to be able to fully understand the concept of 3D-Shapes Geometry material through this subject material because 3DShapes Geometry material is in elementary, junior and senior high school mathematics. Learning of 3D-Shapes Geometry that is exist at elementary, junior high, high school, and college level is related to mathematics critical thinking ability (Setiawan and Sunardi, 2015). The mathematics critical thinking ability is one of the high-level thinking skills that students must be possed. The mathematics critical thinking ability becomes important in mathematics (Hendryawan et al, 2017). This suggests that critical thinking ability are included in general mathematical abilities. Based on PISA published by the OECD, Indonesia's mathematical ability ranks $62^{\text {th }}$ from 70 countries (OECD, 2018). The results of this OECD publication can show that the mathematical abilities in which it includes the mathematics critical thinking ability are still low.

The critical thinking ability is not innate. This ability can develop through the learning process (Cahyono, 2017). Critical thinking in education is the important thing, so it is underpinned by decades of theoretical and practical work (Gelerstein. et al, 2016). This importance can include critical thinking into educational policy documents (Massa, 2014). Critical abilities is one of important generic competence that can be developed by students (Albergaria and Almeida, 2011). Critical thinking ability is high-level thinking skills that make it possible to investigate the assumptions of other people's ideas (Nasution, 2018). According to the research by Aktaş \& Ünlü (2013), critical thinking can develop learning environment of teacher candidates, so they can improve themselves to be qualified teachers. Critical thinking can be learned through practice and awareness, so the students can acquire practical skills and intellectual abilities (Florea and Hurjui, 2015). Students who have the ability to think critically can think rationally by collecting information as completely as possible. Students can proceed to contextualize the merits of rationality in their critical thinking (Dunne, 2015). The indicator of critical thinking according to Facion (Karim, Normaya, 2015) are interpretation, analysis, evaluation, and inference. Interpretation that is to understand from various situations, data, and criterias. Analysis is to identify the link between statement, question, concepts that is needed . Evaluation is to estimate the credibility of the information that is obtained. Inference is identify the things needed to obtain a rational conclusion.

Critical thinking can present in forming geometrics concepts if the sttudents start to arguing skills and mathematical skill to analyze (Dinuţâ, 2015). Learning that can stimulate the critical thinking ability should be learning in which there are activities that are student-centered learning. One of the lessons in 3D-Shapes Geometry that can be used is learning using Geogebra Software. Students can interpret and check their spatial understanding using Geogebra. Learning 3D-Shapes Geometry with GeoGebra is very possible to make students practice their spatial capabilities independently that will grow their self regulated learning.

The existence of student's selfregulated learning will make the student able to interpret, analyze, evaluate, and infer in learning. These abilities will form the critical thinking skills that is included in mathematics learning achievement. This is in accordance with research by Purnomo (2016), that there is a significant influence of self regulated learning on mathematics learning achievement. 


\section{JIPM (Jurnal Ilmiah Pendidikan Matematika), 7(1), September 2018 - 42}

Destia Wahyu Hidayati, Lenny Kurniati

Students who have self regulated learning will responsibly engage in conscious learning without being coerced by others (Prasetyaingsih, Chamdani, and Warsiti, 2014). This awareness actualize a full determination for students to manage their learning process. Students have a full role in designing independently various forms of learning that will be passed. Self regulated learning is a learning activity without depending on others both friends and teachers (Suhendri and Mardalena, 2013). Other opinions about the definition of self regulated learning are learning activities independently, not dependent on others, and have initiative to learn (Fahmy, Wardono, and Masrukan, 2018). Based on the definitions of self regulated learning can be concluded that the self regulated learning is the awareness to learn without a certain help in order to achieve certain learning objectives. According to Zimmerman (Qohar and Sumarno, 2013), components of self regulated learning are: (1) Planning learning independently. In this activity students begin to design the learning, to determine the learning objectives to be achieved, to choose the materials and aid teaching that will be used, to choose the method that will be used to achieve the expected goals. In this research the students prepare 3D-Shapes Geometry teaching materials and install Geogebra software that is provided by lecturers; (2) Monitoring the progress of learning independently. In this activity the students monitor the learning process that is being done. Students with self awareness will construct their learning. Students also consciously and independently ask for help to the lecturer if the student is having difficulty in learning process. In this study, students began to pay attention to information about Geogebra and the examples of questions given by lecturers. Armed with information from the teacher, students are doing on the problem of critical thinking of plane intersection in $3 \mathrm{~d}$ shapes, aterial. Students will ask the lecturer if there are things that make students confused; (3) Evaluate learning independently. At this stage students check their own understanding results using the specific aid teaching. Students can use the Tools "Plane through 3 points" to check the answer from the task of plane intersection in 3D shape material.

Student that has self regulated learning in building their own understanding through Geogebra software will realize the independence of thinking. While students experience independence to think then the students also experience the development of critical thinking ability (Nasution, 2018).

\section{METHOD}

This research was a quantitative research. The material of this research was one of the materials contained in the 3DShapes Geometry subject. That was the plane intersection in 3D-shape material. The research variables were self regulated learning and in mathematics critical thinking ability. The data of self regulated learning was collected through giving the scale of self regulated learning. The data of mathematics critical thinking ability wa collected through the giving of mathematics critical thinking ability about plane intersection in 3D-shape.

This research stemed from the design of learning instruments, there were syllabus, RPS, 3D-Shapes Geometry teaching materials using Geogebra, the scale of self regulated learning, and the question of mathematics critical thinking ability. These learning instruments were validated by two lecturers of Mathematics Education who come from different college graduates. Validation of this learning instruments using mean-test.

The valid learning instruments would be used for learning on the subject of research. The subjects of this research were the students of IKIP Veteran in Mathematics Education who are taking 3D-Shapes Geometry learning. They are 11 students who previously tested the normality of preliminary data that is the data value of the task on the material before plane intersection in 3D shape.

The researcher gave the test of mathematics critical thinking ability and the scale of self regulated learning after they had finished their learning process of plane 
intersection in $3 \mathrm{D}$ shape. The test result of mathematics critical thinking ability is tested normality before further data analysis. If the test of mathematics critical thinking ability was normal, then regression test could be done. Regression test was done by checking the influence and the value influence of self regulated learning to mathematics critical thinking ability.

\section{RESULTS AND DISCUSSION}

The syllabus validation score was 3,64 so it belonged into a valid category. The RPS validation score was 3,64 so it belonged into a valid category. 3D Shapes Geometry object material validation scores reached 3,42 so it belonged into a valid category. The validation score of the mathematics critical thinking ability test was 3,5 so it was also entered in the valid category. The score of self regulated learning scale reaches 3,83 so it belonged into a valid category.

The results of the mathematics critical thinking ability assessment are based on indicators of interpretation, analysis, evaluation, and inference. The interpretation indicator is presented in Table 1.

Table 1. Interpretive Indicators

\begin{tabular}{cl}
\hline Score & \multicolumn{1}{c}{ Interpretation } \\
\hline 1 & Image interpretation error $>50 \%$ \\
2 & Image interpretation error $50 \%$ \\
3 & Image interpretation is correct \\
\hline
\end{tabular}

The analysis indicators are presented in Table 2.

Table 2. Indicator Analysis

\begin{tabular}{cl}
\hline Score & \multicolumn{1}{c}{ Analysis } \\
\hline 1 & Can not relate the necessary concepts \\
2 & $\begin{array}{l}\text { Can link the concepts needed but } \\
\text { there is still something wrong }\end{array}$ \\
3 & $\begin{array}{l}\text { Can link the necessary concepts } \\
\text { correctly }\end{array}$ \\
\hline
\end{tabular}

Evaluation indicators are presented in Table 3.

Table 3. Evaluation Indicators

\begin{tabular}{cl}
\hline Score & \multicolumn{1}{c}{ Evaluation } \\
\hline 1 & The workflow does not work \\
2 & $\begin{array}{l}\text { The work flow is appropriate but not } \\
\text { coherent }\end{array}$ \\
3 & $\begin{array}{l}\text { The work flow is appropriate and } \\
\text { coherent }\end{array}$ \\
\hline
\end{tabular}

The analysis indicators are presented in Table 4.

Table 4. Inference Indicators

\begin{tabular}{cl}
\hline Score & \multicolumn{1}{c}{ Inference } \\
\hline 1 & $\begin{array}{l}\text { There is an answer to the problem } \\
\text { but is still wrong } \\
2\end{array}$ \\
There is a correct answer according \\
to the problem but the process is still \\
wrong \\
There is a correct answer according \\
to the problem with the correct \\
process
\end{tabular}

Normality test results from preliminary data are presented in Table 5.

Table 5 . Initial Data Normality Test

\begin{tabular}{|c|c|c|}
\hline & $\begin{array}{l}\text { Kolmogorov- } \\
\text { Smirnov a }\end{array}$ & Shapiro-Wilk \\
\hline & \multicolumn{2}{|c|}{ Statistic df Sig. Statistic df Sig. } \\
\hline value & .14411 .200 & .97211 .908 \\
\hline
\end{tabular}

The sig value shows $0,200>0,05$ so preliminary data is distributed normal.

Preliminary data indicate that the data is normally distributed, so that it can be continued with the test of critical mathematical thinking ability and the scale of learning independence. The results of the normality test of mathematics critical thinking ability are presented in Table 6 .

Table 6 . Test Normality Test Maths Critical Thinking Skills

\begin{tabular}{llllllll}
\hline & \multicolumn{3}{c}{$\begin{array}{c}\text { Kolmogorov- } \\
\text { Smirnov }\end{array}$} & \multicolumn{4}{c}{ Shapiro-Wilk } \\
\hline & Statistic & df & Sig. & Statistic & df & Sig. \\
Nilai & & & & & & \\
post & .171 & 11 & $.200 *$ & .954 & 11 & .694 \\
\hline
\end{tabular}

Sig of mathematics critical thinking ability test is of $0,200>0,05$, we can say that the data of mathematics critical thinking ability test were normally distributed.

The influence of self regulated learning to mathematics critical thinking ability can be tested by regression test. Regression test results are presented in Table 7. 
Table 7 . Regression Test of Learning Independence of Critical Thinking Ability

\begin{tabular}{llllll}
\hline \multicolumn{1}{c}{ Model } & $\begin{array}{c}\text { Sum of } \\
\text { Squares }\end{array}$ & df & $\begin{array}{c}\text { Mean } \\
\text { Square }\end{array}$ & F & Sig. \\
\hline 1 Regression & 344602 & 1 & 344602 & 7.576 & .022 \\
Residual & 409398 & 9 & 45489 & & \\
Total & 754,000 & 10 & & & \\
\hline
\end{tabular}

Based on Table 7, the sig score of regression test is $0,022<0,05$, so it can be said that there is an influence between the self regulated learning to the regression test. Coefficient of correlation of influence the self regulated learning of regression test is presented in Table 8 .

Table 8. Correlation of Self Regulated Learning to Mathematics Critical Thinking Ability

\begin{tabular}{ccccc}
\hline Model & $\mathbf{R}$ & $\begin{array}{c}\mathbf{R} \\
\text { Square }\end{array}$ & $\begin{array}{c}\text { Adjusted R R } \\
\text { Square }\end{array}$ & $\begin{array}{c}\text { Std. Error } \\
\text { of the } \\
\text { Estimate }\end{array}$ \\
\hline 1 & $.676^{\text {a }}$ & .457 & .397 & 6.74453 \\
\hline
\end{tabular}

Based on Table 8, there is an influence between self regulated learning and regression test of $45,7 \%$.

Learning 3D-Shapes Geometry using Geogebra is very possible for students to participate in learning process actively. Students can explore his knowledge of 3D-Shapes Geometry as much as possible through Geogebra. The advantages of using Geogebra on the material of plane intersection in 3Dshape are: (1) The accuracy to draw 3Dshapes with certain criteria is assured. This is because there is very little chance of error in measurement when using Geogebra software. Unlike the case when drawing 3D-shapes manually, errors can be done deliberately like the accuracy of measuring the length, accuracy in making straight lines, and accuracy in making the angle; (2) Efficient time. The drawing process manually will take much longer than drawing in Geogebra software, because students don't only think about the size of the image but also predict how to draw the correct shape; (3) Not too much of equipment needed in drawing like a run, ruler, pencil, and bow; (4) If an error occurs, the student can change the wrong step without starting from the beginning of the drawing. Students can use the "Undo" Tool to restore the previous image results. Students don't need to be afraid to try to solve problems by utilizing various Tools in Geogebra software. The location of Tools "Undo" is shown in Figure 1.

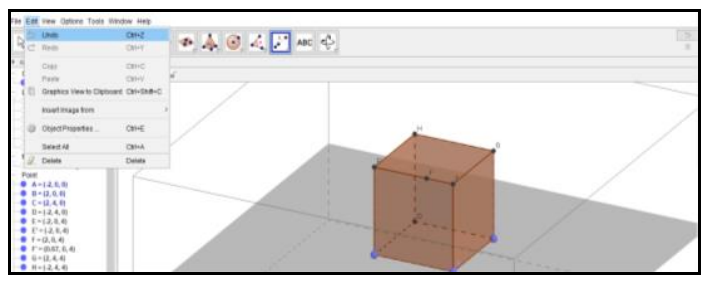

Figure 1. Undo location on Geogebra

(5) Students can check the correctness of the result of plane intersection in 3D-shapes using "Plane through 3 points" Tool. The location of the "Plane through 3 points" Tool is presented in Figure 2.

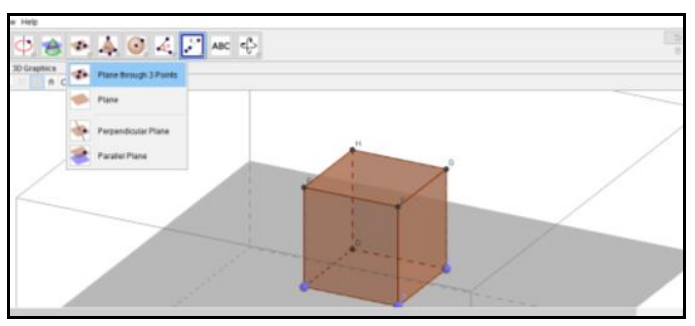

Figure 2. Location of the Tool "Plane through 3 points"

(6) Students can create segments of lines with no length of integers based on a certain scale easier. Tools that can be used is " Dilate from point ". Location of Tools "Dilate from point" is shown in Figure 3.

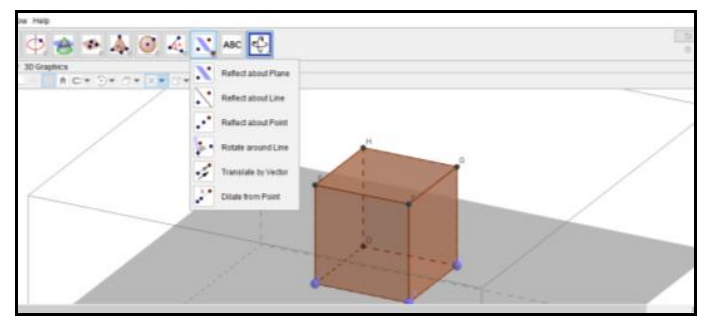

Figure 3. The Process of Making Length of Line Segment with Specific Scale

(7) Students can view 3D-shapes in different angles with Tools "Rotate". This is very 
helpful for students to look for plane intersection in 3D-shapes because it is possible that the point on 3D-shape will be covered by the side in the wake of it. This can be seen from different angles of view when students is viewing the plane intersection in 3D-shape. Examples of such differences are shown in Figure 4, Figure 5, and Figure 6.

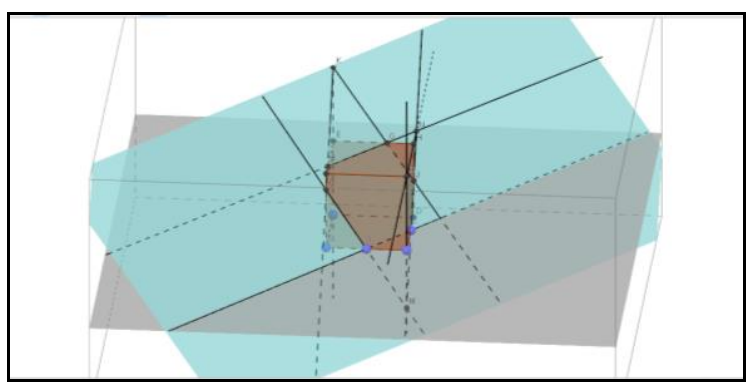

Figure 4. Plane Intersection in 3D-Shape Viewpoint 1

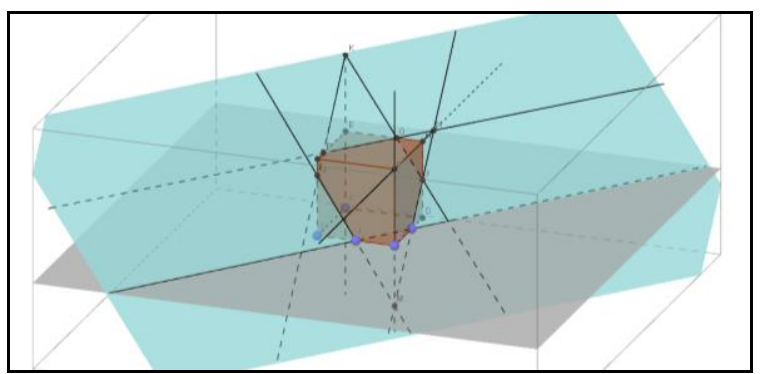

Figure 5. Plane Intersection in 3D-Shape Viewpoint 2

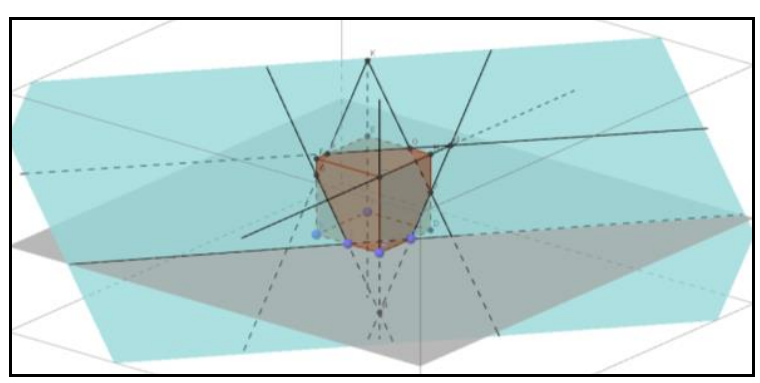

Figure 6. Plane Intersection in 3D-Shape ViewPoint 3

There are many variation clarity of the plane intersection in 3D-shape based on the base and frontal plane. For example the plane intersection in 3D-shape through the same base plane but different frontal plane are shown in Fig. 7, Fig. 8, Fig. 9, and Fig. 10.

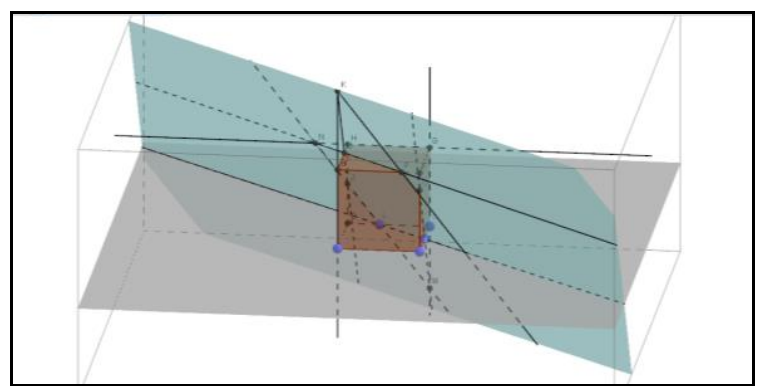

Figure 7. ABCD Base Plane, ABFE Frontal Plane

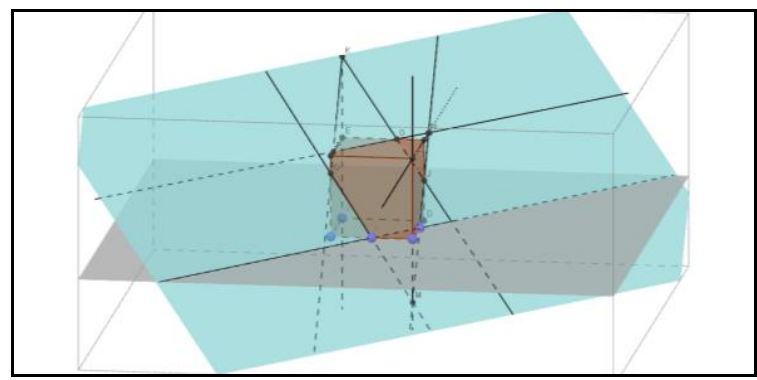

Figure 8. ABCD Base Plane, BCGF Frontal Plane

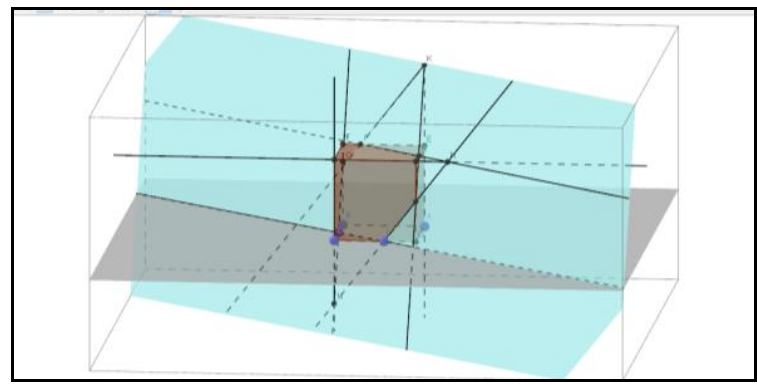

Figure 9. ABCD Base Plane, CDHG Frontal Plane

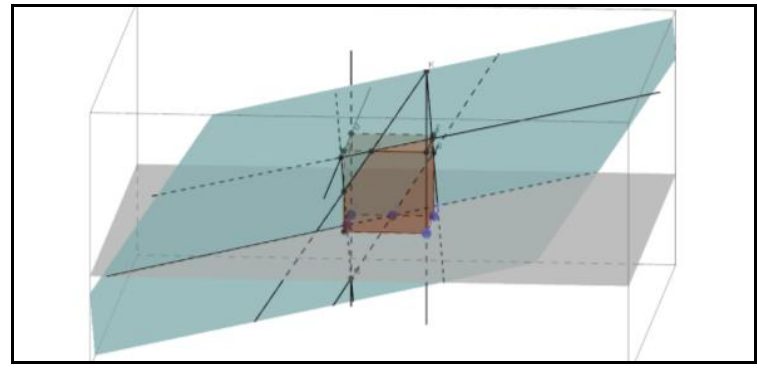

Figure 10. ABCD Base Plane, DAEH Frontal Plane

The advantages using Geogebra in learning process are also shown in research by Agung (2017), the images that is produced on Geogebra are more accurate so that the mathematical concepts can be met visually. Another advantage is using Geogebra in learning can create a students critical ability from students (Supriadi, 2015). This advantage will have a positive impact for students in 
learning 3D-Shapes Geometry. Students do not have to wait face-to-face with lecturers to study 3D-Shapes Geometry because Geogebra software can be easily installed on laptop or student's PC at home, so that self regulated learning will be formed through learning using Geogebra. This is in accordance with research conducted by Fahmy, Wardono, and Masrukan (2018) which is one of the advantages of learning using Geogebra is the student can independently develop his knowledge and can more enjoy in their mathematics learning, especially geometry material. According to Supriadi (2018), interactive electronic-based learning aid gives students the flexibility to repeat and to study it anytime and anywhere without presenting teachers in the process of understanding learning materials. Geogebra and critical thinking as reflective tools which can develop student understanding of mathematics (Udi and Radakovic, 2012).

Based on the results of this, there was an influence of self regulated learning to the mathematics critical thinking ability $45,7 \%$, so self regulated learning can affect the mathematics critical thinking ability by $45,7 \%$. The higher self regulated learning can make the higher mathematics critical thinking ability. Critical thinking ability includes in mathematics learning result, so the result of this research is in accordance with research conducted by Suhendri and Mardalena (2013), there is influence of self regulated learning to the result of learning mathematics. Critical thinking skill can improve mathematical achievement (Jacob, 2012). The importance of critical thinking is not only to academic fields, but also to problem solving platforms (Kezer and Turker, 2012). Developing critical thinking represent at students is the important task of mathematics education (Maričića and Șpijunovićb, 2015). The significant effect of students' self regulated learning on mathematics learning achievement is $30,4 \%$ is also found in research conducted by Purnomo (2016). According to Early, Winarti, and Supriyono (2018), the correlation of self regulated learning and mathematics critical thinking ability show a positive correlation, so that if the self regulated learning is higher then the ability of critical thinking is also higher.

The existence of self regulated learning will make students consciously have a sense of responsibility towards the planning, implementation, and evaluating the learning process independently. This awareness will make the intensity of the learning process to be high. The learning that has many self regulated activites such as think, reason, ask, and question can increase crtitical thinking (Altintas dan Ozdemir, 2012). Someone tend to have a high intensity of mathematics learning process if they have high self regulated learning as well (Ningsih and Nurrahmah, 2016). The high intensity of the learning process will make the students more interpret, analyze, evaluate, and infer the 3D-Shapes Geometry concepts, so that the rational thinking ability which is the base of mathematics critical thinking ability will be formed.

\section{CONCLUSION}

The conclusion of this study is the relationship between self regulated learning and mathematics critical thinking ability by $45,7 \%$. The higher self regulated learning makes the higher mathematics critical thinking ability, on the contrary the lower students' self regulated learning will make lower mathematics critical thinking ability.

Based on the conclusions, the suggestion of this research are 1) teachers or lecturers should be able to create innovative learning and to demand an active role in learning, especially using Geogebra that has been proven to establish self regulated learning so that mathematics critical thinking ability can be created, 2) students should use PC or laptop individually for more flexibility to explore in learning using Geogebra, but if students have difficulty to bring a PC or laptop so learning process can be hold in Computer Laboratory which there is a whiteboard there, 3 ) learning process using Geogebra would be better if in the first meeting, students have been asked to bring an individual laptop or to go to the Computer Laboratory to introduce Geogebra, so they are not awkward in learning to use Geogebra. 


\section{REFERENCES}

Aktaş, G. S. and Ünlü, M. (2013). Critical Thinking Skills of Teacher Candidates of Elementary Mathematics. ProcediaSocial and Behaviorial Sciences. 93, 831-835

Albergaria, P. and Almeida. (2011). Critical Thinking, Questioning and Creativity as Components of Intelligence. ProcediaSocial and behavioral Sciences. 30, 357-362

Altintas, E. and Ozdemir, A. S. (2012). The Effect of Teaching with The Mathematics Activity Based on Purdue Model on Critical Thinking Skills and mathematics Problem Solving Attitudes of Gifted and Non-Gifted Students. ProcediaSocial and Behavioral Sciences. 46, 853-857

Agung, S. 2017. Pemanfaatan Aplikasi Geogebra dalam Pembelajaran Matematika SMP. Prosiding Seminar Nasional Universitas Cokroaminoto Palopo. 3 (1), 312-322

Dunne, G. (2015). Beyond Critical Thinking to Critical Being: Critically in Higher Education and Life. International Journal of Education Research. 71, 86-99

Dinuţâ, N. (2015). The Use of Critical Thinking in teaching Geometric Concepts in Primary School. Procedia-Social and Behavioral Sciences. 180, 788-794

Early, O. E., Winarti, E.R., dan Supriyono. (2018). Analisis Kemampuan Berpikir Kritis Matematis Ditinjau dari Kemandirian Siswa Kelas VIII melalui Pembelajaran Model PBL Pendekatan Saintifik Berbantuan Fun Pict. PRISMA. Prosiding Seminar Nasional Matematika UNNES. I

Fahmy, A. F. C., Wardono, dan Masrukan. (2018). "Kemampuan Literasi Matematika dan kemandirian Belajar Siswa pada Model Pembelajaran RME Berbantuan Geogebra". PRISMA Prosiding Seminar Nasional Matematika 1

Florea, N. M. and Hurjui, E. (2015). Critical Thinking in Elementary School Children. Procedia-Social and Behavioral Sciences. 180, 565-572

Gelerstein, D. et al. (2016). Designing and Implementing A test for Measuring Critical Thinking in Primary School. Thinking Skills and Creativity. 20, 40-49 Hidayati, D.W. (2017a). Diagnosa Kesulitan Metacognitive Awareness terhadap Proses Pemecahan Masalah Matematika. JNPM (Jurnal Nasional Pendidikan Matematika). 1 (2), 206-217

Hidayati, D. W. (2017b). Penerapan Problem Based Learning Berbasis Self-Directed Learning Oriented Assessment terhadap Kemampuan Pemecahan Masalah. MEDIVES. 1 (1), 17-24

OECD. (2018). PISA 2015: PISA Result In Focus. Drive: OECD

Hendryawan, et al. (2017). Analisis Kemampuan Berfikir Kritis Matematis Siswa SMP Tingkat Rendah pada Pembelajaran Berbasis Masalah dengan Green's Motivational Strategies. AKSIOMA. 8 (2), 50-58

Jacob, S. M. (2012). Mathematical Achievement and Critical Thinking Skills in Asynchronous Discussion Forums. Procedia-Social and behavioral Sciences. 31, 800-804

Karim dan Normaya. (2015). Kemampuan Berpikir Kritis Siswa dalam Pembelajaran Matematika dengan Menggunakan Model Jucama di Sekolah Menengah Pertama. EDU-MAT Jurnal Pendidikan Matematika. 3 (1),92-104

Kemendikbud. (2016). Permendikbud Nomor 21 tentang Standar Isi Pendidikan Dasar dan Menengah. Jakarta: Kemendikbud

Kezer, F. and Turker, B. (2012). Comparison of The Critical Thinking Dispositions of (Studying in The Secondary Science and Mathematics Division) Preservice Teachers. Procedia-Social and Behavioral Sciences. 46, 1279-1283

Maričića, S. and Şpijunovićb, K. (2015). Developing Critical Thinking in Elementary Mathematics Education through A Suitable Selection of Content and Overall Student Performance. Procedia-Social and Behavioral Sciences. 180, 653-659

Massa, S. (2014). The Development of Critical 
Thinking in Primary School: The Role of Theachers' Beliefs. Procedia-Social and Behavioral Sciences. 141, 387-392

Nasution, S. W. R. (2018). Penerapan Model Inkuiri Terbimbing (Guided Inquiry) dalam Meningkatkan Kemampuan Berpikir Kritis pada Pembelajaran Fisika. Jurnal Education and Development. 3 (1), 1-5 Ningsih, R dan Nurrahmah, A. (2016). Pengaruh Kemandirian Belajar dan Perhatian Orang Tua Terhadap Prestasi Belajar Matematika. Jurnal Formatif. 6 (1), 73-84

Prasetyaningsih, A., Chamdani, M., dan Warsiti. (2014). Hubungan Kemandirian Belajar dan Interaksi Edukatif Dengan Hasil Belajar IPS Siswa Kelas IV SD
Sekecamatan Purworejo. Kalam Cendikia PGSD KEBUMEN, 2 (3), 16-23

Purnomo, Y. (2016). Pengaruh Sikap Siswa pada Pembelajaran Matematika dan Kemandirian Belajar Siswa terhadap Prestasi Belajar Matematika. JKPM. 2 (1), 93-105

Udi, E. A. and Radakovic, N. (2012). Teaching Probability by using Geogebra Dynamic Tool and Implemanting Critical Thinking Skills. Procedia-Social and Behavioral Sciences. 46, 4943-4947

Wahyuni, A. (2017). Analisis Hambatan Belajar Mahasiswa pada Mata Kuliah Kalkulus Dasar. JNPM (Jurnal Nasional Pendidikan Matematika). 1 (1). 10-23 